\title{
Maaseudun rakennemuutoksessa mahdollisuuksia
}

\author{
Leena Rantamäki-Lahtinen ${ }^{1)}$, Anne Kumpulehto ${ }^{2)}$ Antti Hannukkala ${ }^{2)}$ Marja Uusitalo ${ }^{2)}$, \\ ${ }^{1)}$ Maa- ja elintarviketalouden tutkimuskeskus, Taloustutkimus, 31600 Jokioinen, \\ ${ }^{2)}$ Maa- ja elintarviketalouden tutkimuskeskus, Kasvintuotannontutkimus, 96900 Rovaniemi, \\ etunimi.sukunimi@mtt.fi
}

\section{Tiivistelmä}

Maatalouden toimintaympäristö muuttuu koko ajan. Maatalouden rakennemuutosten ja tukipolitiikan uudistusten vuoksi maatilojen määrän ennustetaan vähenevän voimakkaasti. Lisäksi toiminta keskittyy ja tilakoko kasvaa Lapin läänin alueella.

Yrittäjän ikä, tilan kannattavuuden lasku sekä tuotantovälineiden uusimisen tarve vaikuttavat yrittäjän mahdollisuuksiin tai halukkuuteen jatkaa maatilan toimintaa tai etsiä uusia tuotantovaihtoehtoja. Maataloudesta luopuvilla tiloilla on yleensä paljon sekä fyysisiä että henkisiä resursseja harjoittaa uutta elinkeinotoimintaa. Tulevaisuuden ennakointiin ja eri tekijöiden yhteisvaikutusten arviointiin ja päätöksentekoon yrittäjä kaipaa usein asiantuntijoiden tukea.

Multimaaseutu hanke tukee maatiloja ja maaseutuyrityksiä selvittämällä tulevaisuuden toimintavaihtoehtoja ja antamalla neuvoja uuden toiminnan käynnistämisessä. Neuvonnan ja tutkimuksen parissa työskentelevät asiantuntijat muodostivat hankkeessa tiimejä, joissa tutkimustieto ja käytännön osaaminen palvelivat yritystoiminnan kehittämistä. Samalla luotiin yhteistyömallia, joissa asiantuntijaja tutkimusorganisaatiot kytkettiin entistä tiiviimmin uusien toimialojen ja yritystoiminnan kehittämiseen. Tällaisessa tiimityöskentelymallissa voidaan tutkimustakin suunnata uusiin haasteisiin ja parantaa sen vaikuttavuutta. Neuvonnan ja tutkimuksen räätälöimä toimintasuunnitelma on hyvä startti uuteen yrittäjyyteen.

Hankkeen aikana on selvinnyt, että on tarkoituksenmukaista tehdä toimialaselvityksiä, jotka tukevat hankkeen toteuttamista tuottamalla informaatiota ja antamalla välineitä kehittämistyöhön. Peltoja bioenergiaselvityksen tavoitteena oli tutkia Lapissa menestyvien peltokasvien soveltuminen biokaasutuotannon raaka-aineeksi sekä biomassan että laadun osalta. Peltoenergiatutkimuksessa erilaisten kasvien tuottokykyä verrattiin ruokohelpeen. Lisäksi selvitettiin laajemmin bioenergian käyttömahdollisuuksia. Maaseutumatkailu on kehittyvä toimiala Lapissa. Matkailu liittyy lähes kahteen kolmasosaan käynnistyvistä yrityshankkeista. Selvityksen tavoitteena oli laatia toimintamalleja matkailupalveluiden tuotantoon sekä osoittaa kannattavuuden edellytykset ja menestystekijät. Lisäksi selvitettiin emolehmätuotannon ja lihan jatkojalostuksen reunaehtoja ja toteuttamis- ja kannattavuusedellytyksiä koko tuotantoketjussa. Toimialaselvitysten hyöty kohdistuu ensisijaisesti hankeyritysten kehittämiseen, mutta tieto on jatkossa hyödynnettävissä myös muiden maaseutuyritysten toiminnan kehittämisessä.

Asiasanat: maaseudun rakennemuutos, maaseutuyrittäjyys, kehittyvät toimialat 


\section{Johdanto}

Hankkeen tavoitteena oli luoda uusia elinkeinollisia mahdollisuuksia maatiloille sekä maaseutuyrityksille ja ohjata siten taantuvien alueiden rakennemuutosta.

Tilojen elinkeinojen ja uusien toimialojen kehittäminen perustuu pitkälti palvelujen ja tuotteiden kysyntään Lapin väestö- ja matkailukeskuksien muodostamilla markkina-alueilla, jotka ovat maakunnan alueellisia vetureita. Hankkeessa pyrittiin tarve- ja kysyntälähtöisyyteen sekä uusien tuotantomahdollisuuksien kartoituksessa, tuotekehityksen edistämisessä, tuotannon logistiikan kehittämisessä, markkinointi- ja tuotanto-osuuskuntien perustamisessa että yrittäjien vuorovaikutuksen lisäämisessä.

\section{Aineisto ja menetelmät}

Hankkeeseen osallistuvien maatilojen sekä maaseutuyritysten osalta selvitettiin uudet elinkeinolliset vaihtoehdot ja avustettiin uuden yritystoiminnan käynnistämisessä. Esimerkkiyrityksille luotiin toimintamalli asiantuntijoiden kanssa (Kuva 1).

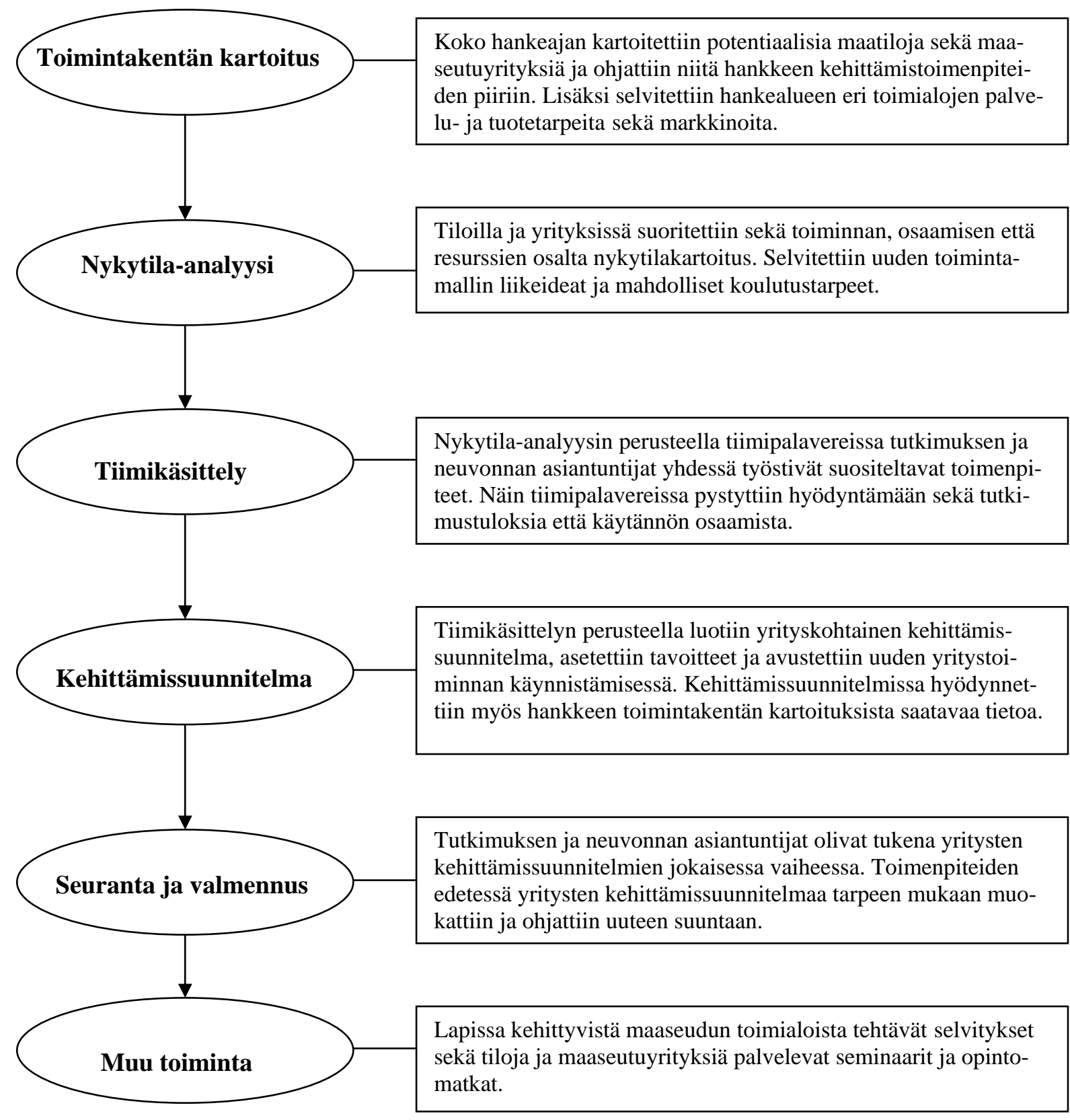

Kuva 1. Kaavio hankkeen toimintamallista. 


\section{Tulokset ja tulosten tarkastelu}

Lapin maaseutuyrityksistä 70 prosenttia on maaseudun pienyrityksiä, jotka voidaan jakaa kolmeen ryhmään: perustuotantotiloihin, monialaisiin tiloihin ja muihin maaseudun pienyrityksiin. Lapin TEkeskuksen alueella on koko maahan verrattuna suhteessa eniten monialaisia tiloja, ja niiden märä on edelleen kasvussa (Taulukko 1). Kaikkiaan 45 prosenttia lappilaisista aktiivitiloista harjoittaa myös muun toimialan yritystoimintaa. Perinteisen maa- ja metsätalouden rinnalle on tilan toimintaa monipuolistamaan tuotu mukaan mm. tuotteiden jatkojalostamista ja matkailupalveluja. Maaseutuyritysten toimialat vaihtelevat selvästi eri seutukuntien välillä (Taulukot 2 ja 3).

Energiayrittäjyys on merkittävä vaihtoehto maaseudun toiminnoissa. Hankkeen puitteissa alettiin selvittää peltobioenergiakasvien soveltuvuutta sekä biokaasun tuotantoon että polttoon Lapin olosuhteissa. Kokeita on tehty sekä Rovaniemellä että Kittilässä. Ensimmäiset tulokset osoittavat, että kasvilajien välillä on selviä eroja käytettävyydessä energiatuotannossa (Taulukot 4 ja 5).

Lapin kehittyvistä toimialoista saatiin tietoa, jota tarvitaan taustatiedoksi maaseutuyritysten muutosohjauksessa.

Taulukko 1. Lappilaisen maaseudun pienyritysten rakenne vuosina 2000 - 2005 (Maaseudun pienyritysrekisteri, Tilastokeskus, Tike, MTT).

\begin{tabular}{lccc}
\hline & $\mathbf{2 0 0 0} *$ & $\mathbf{2 0 0 2 / 2 0 0 3}$ & $\mathbf{2 0 0 4} * \boldsymbol{2 0 0 5}$ \\
\hline Perustuotantotilat & 1698 & 1277 & 1058 \\
Monialaiset tilat & 497 & 795 & 864 \\
Ilman maatilakytkentää toimivat & & & \\
maaseudun pienyritykset & 3853 & 3848 & 483 \\
Yhteensä & 6048 & 5920 & 6405 \\
\hline
\end{tabular}

* Monialaisten tilojen luokituksesta puuttui vuonna 2000 porotalous, muina vuosina se on huomioitu. ${ }^{* *}$ Maaseudun pienyritysrekisterin aluejakoa päivitettiin vuonna 2004.

Taulukko 2. Maaseudun elintarvikealan yritykset seutukunnittain 2004 (Maaseudun pienyritysrekisteri, Tilastokeskus, Tike, MTT).

\begin{tabular}{lrcccc}
\hline seutukunnat & $\begin{array}{c}\text { yrityksiä } \\
\text { kpl }\end{array}$ & $\begin{array}{c}\text { henkilöstö } \\
\text { HTV }\end{array}$ & $\begin{array}{c}\text { liikevaihto } \\
\mathbf{1 0 0 0} €\end{array}$ & $\begin{array}{c}\text { henkilöstö/ } \\
\text { yritys }\end{array}$ & $\begin{array}{c}\text { liikevaihto/ } \\
\text { yritys }\end{array}$ \\
\hline 191 Rovaniemen sk & 14 & 16 & 1760 & 1,13 & 126 \\
192 Kemi-Tornion & 9 & 13 & 918 & 1,39 & 102 \\
193 Torniolaakso sk & 5 & 18 & 2515 & 3,52 & 503 \\
194 Itä-Lapin sk & 8 & 22 & 1505 & 2,79 & 188 \\
196 Tunturilapin sk & 14 & 16 & 1624 & 1,17 & 116 \\
197 Pohjois-Lapin sk & 17 & 34 & 3713 & 1,99 & 218 \\
kaikki & 67 & 119 & 12036 & 1,77 & 180 \\
\hline
\end{tabular}

Taulukko 3. Maaseudulla sijaitsevat matkailu- ja virkistyspalvelualan pienyritykset seutukunnittain 2004 (Maaseudun pienyritysrekisteri, Tilastokeskus, Tike, MTT).

\begin{tabular}{lrrccc}
\hline seutukunnat & $\begin{array}{c}\text { yrityksiä } \\
\text { kpl }\end{array}$ & $\begin{array}{c}\text { henkilöstö } \\
\text { HTV }\end{array}$ & $\begin{array}{c}\text { liikevaihto } \\
\mathbf{1 0 0 0} €\end{array}$ & $\begin{array}{c}\text { henkilöstö/ } \\
\text { yritys }\end{array}$ & $\begin{array}{c}\text { liikevaihto/ } \\
\text { yritys }\end{array}$ \\
\hline 191 Rovaniemen sk & 65 & 100 & 8781 & 1,54 & 135 \\
192 Kemi-Tornion & 57 & 90,1 & 7698 & 1,58 & 135 \\
193 Torniolaakso sk & 32 & 52,7 & 4107 & 1,65 & 128 \\
194 Itä-Lapin sk & 55 & 94,5 & 7842 & 1,72 & 143 \\
196 Tunturilapin sk & 170 & 310,2 & 25563 & 1,82 & 150 \\
197 Pohjois-Lapin sk & 109 & 265,2 & 22621 & 2,43 & 208 \\
kaikki & 488 & 913 & 76613 & 1,87 & 157 \\
\hline
\end{tabular}


Taulukko 4. Monivuotisten bioenergiakasvien sato Rovaniemellä ja Kittilässä 2007.

\begin{tabular}{lrr}
\hline Kasvilaji & $\begin{array}{r}\text { Sato kgka/ha } \\
\text { Rovaniemi }\end{array}$ & $\begin{array}{r}\text { Sato kgka/ha } \\
\text { Kittilä }\end{array}$ \\
\hline Timotei (Iki) & 11723 & 5736 \\
Nurminata & 9770 & 7821 \\
Ruokonata & 10383 & 5993 \\
Ruokohelpi & 10513 & 5059 \\
Rehukattara & 0 & 2212 \\
Niittynurmikka & 3635 & 3028 \\
Puna-apila & 7609 & 2976 \\
Timotei (Grinstad) & 11607 & 605 \\
Nurminata, poltto & 10120 & \\
Ruokonata, poltto & 11293 & \\
Ruokohelpi, poltto & 9352 & \\
Rehukattara, poltto & 2503 & \\
\hline
\end{tabular}

Taulukko 5. Yksivuotisten bioenergiakasvien sato Rovaniemellä ja Kittilässä 2006 - 2007.

\begin{tabular}{lrr}
\hline Kasvilaji & Sato kgka/ha & Sato kgka/ha \\
Rovaniemi & Kittilä \\
Ital. raiheinä & 5826 & 3247 \\
West. raiheinä & 6343 & 4224 \\
Naattinauris & 3067 & 2058 \\
Rehurapsi & 2475 & 1552 \\
Ohra & 3221 & 7259 \\
Kaura & 2376 & 5795 \\
Ruis & 4705 & 2573 \\
Ruisvirna & 3045 & 1663 \\
Ohra, poltto & 5245 & \\
Kaura, poltto & 5709 & 1114 \\
Hamppu, poltto & 5500 & \\
\hline
\end{tabular}

\section{Johtopäätökset}

Monialaisuus kertoo osaltaan siitä, että lappilaisilla maatiloilla on kyky omaksua uusia toimintatapoja. Muutosohjausta ja tukea kuitenkin tarvitaan, koska uuden toiminnan käynnistäminen edellyttää melko isoja investointeja. Erityisesti elintarvikkeiden jatkojalostus ja matkailu vaativat perusmaatalouteen verrattuna toisenlaisia tapoja tehdä tuotekehitystä, markkinoida ja myydä tilan tuotteita ja palveluja. Keskeistä on kasvavien markkinoiden tunnistaminen ja taantuvien alueiden kehittäminen.

Maatilojen ja maaseutuyritysten toimintamalleja on pyrittävä tarkastelemaan seutukunnittain, koska Lapin olosuhteen voivat vaihdella eri osissa hyvinkin paljon, eikä toimintaympäristö ei ole kaikkialla samanlainen. Maaseutuyrityksen sijainti ei sinällään vaikuta yrityksen menestymiseen, vaan oleellista on valita ympäristöön soveltuvat tuotteet ja toimintatavat, minkä poronlihan ja matkailun alueellinen keskittyminen maakunnan harvaan asuttuihin pohjoisosiin osoittaa. Kysyntä, asiakkaat ja kilpailu syrjäisillä seuduilla ovat erilaisia kuin kaupunkien läheisyydessä. Tämä on liiketoimintaa suunniteltaessa otettava huomioon ja valittava sopivat kohderyhmät sekä tuotteet ja palvelut. Kaikkien ei kannata tehdä samaa, vaan tuotteet kannattaa erilaistaa ja räätälöidä erilaisille toisiaan täydentäville asiakasryhmille.

Biomassan tuottaminen Lapin pelloilla oikean kasvilajivalintojen jälkeen bioenergian raakaaineeksi on alustavien tutkimusten mukaan yksi tuotantovaihtoehto Lapin maatiloilla. Tuotannon kannattavuuteen vaikuttaa vielä merkittävästi tukipoliittiset ratkaisut.

Hankkeen tulokset osoittavat, että maatalouden rakennemuutoksessa on myös mahdollisuuksia. 